\title{
Teaming up in defence
}

The beewolf populates its antennae with an endosymbiotic Streptomyces species to protect its larvae from fungal attack, according to a report published in Current Biology.

The beewolf is a digger wasp that constructs burrows in sandy soil. The female stings and paralyses honeybees before transporting them back to the burrow. She places paralysed bees into cells built in the burrow and uses a cephalic-gland secretion to embalm them. An egg is laid on the paralysed bee(s) and the cell is sealed off. Embalming the bee prevents decomposition, which would involve microorganisms that might harm the larvae, which hatch and feed on the bee, overwinter in a cocoon and emerge the following spring.

The female secretes a white substance from her antennal glands that orients newly-hatched wasps, enabling successful emergence of mature insects. However, Kaltenpoth et al. now reveal that the same substance also protects larvae from microbial attack. Using scanning electron microscopy, they detected cells and spores characteristic of actinomycete species in the white substance. Cultivation-independent PCR, using DNA isolated from the females' antennae and primers specific for actinomycete-16S rRNA sequences, showed that the species present was most similar to the Streptomyces armeniacus group. When DNA isolated from the antennae of different beewolf populations was analysed, identical sequences were found, indicating that this insect-bacterial relationship is obligate. Fluorescence in situ hybridization (FISH) with a probe specific for the new species stained bacteria in the white substance and in the antennae of beewolf females, but not in control strains of other bacteria.

Streptomyces are renowned for secondary metabolite production, but this is the first example of an endosymbiosis involving a streptomycete. Prior to metamorphosis, larvae spin a cocoon, and FISH showed that more streptomycetes were present on new cocoons than those from which the larvae had hatched. Bioassays showed that far less fungal growth occurred on new cocoons, even in the absence of a larva. Therefore, the streptomycetes probably protect the larva from fungal

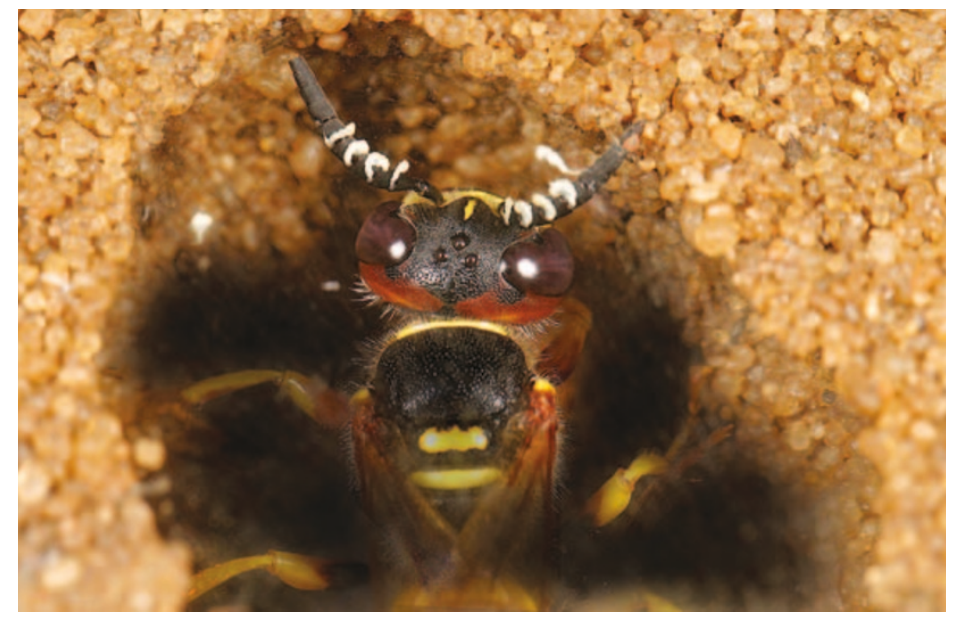

Female European beewolf (Philanthus triangulum, Hymenoptera, Crabronidae) in front of its burrow. Image courtesy of Erhard Strohm, University of Würzburg, Germany. attack. Finally, in brood cells lacking the white substance, larval survival was drastically reduced. How the bacteria benefit from the association remains to be seen.

In another actinomycete-insect symbiosis, leaf-cutter ants, which tend fungus gardens in their nests for nutrition, carry an actinomycete symbiont from the Pseudonocardiaceae family on their cuticle. The symbiont produces compounds that inhibit the growth of a fungus that parasitizes the fungus gardens.

Defence relationships between insects and microorganisms might be more common than previously thought.

Susan Jones

\section{(1) References and links} et al. Symbiotic bacteria protect wasp larvae from fungal infestation. Curr. Biol. 15, 475-479 (2005) ORIGINAL RESEARCH PAPER Kaltenpoth, $M$. 